\title{
Analysis on the Necessity of Real Estate Enterprises to Transform the Asset-Light Operation Mode: A Case Study of China Fortune Land Development
}

\author{
Zhirong Shen ${ }^{1}$ Yun Shui ${ }^{1, *}$ \\ ${ }^{1}$ Jiangsu University of Science and Technology Zhenjiang, Jiangsu 212000, China \\ *Corresponding author. Email: 354590866@qq.com
}

\begin{abstract}
With the rapid development of China's economy, the optimization of financing environment for real estate enterprises and the support of national policies, the real estate industry of China is entering the "stock era". At the same time in the context of the escalation of the trade war, real estate enterprises will also face serious challenges. As a new operation mode conforming to China's economic system and market demand, the assetlight model provides a new idea for the strategic transformation of many real estate enterprises [1]. This article begins with an overview of the asset-light operating model, analyses the necessity of the transformation of China Fortune Land Development into asset light operation mode, and puts forward corresponding suggestions for the transformation of China Fortune Land Development into asset light operation mode.
\end{abstract}

Keywords: real estate enterprises, asset-heavy, asset-light, strategic transformation

\section{INTRODUCTION}

This article selects China Fortune Land Development as the research object, firstly it introduces the concept of the asset-light model, and then combines the industry background and relevant data in the company's annual report to analyse the financial problems that China Fortune Land Development faces under the current asset operation model, and elaborates the necessity of adopting an assetlight operation model. Finally it puts forward corresponding suggestions for the problems that have arisen, to provide useful help for China Fortune Land Development and stable development of the entire real estate industry.

\section{REAL ESTATE ENTERPRISES TO TRANSFORM THE ASSET-LIGHT OPERATION MODE}

\subsection{Implications of the asset-light operation model of real estate companies}

The real estate industry's asset-light operation mode refers to that the real estate development enterprises no longer invest too much capital in the asset-heavy such as inventory and fixed assets, but invest the capital in the light assets such as long-term accumulated customer resources and brand effects, so as to gain profits by creating their own competitive advantages.

\subsection{The financial problems faced by the asset operation mode of China Fortune Land Development}

\subsubsection{The high asset liability ratio increases the pressure of business operation}

The level of asset liability ratio reflects the degree of guarantee and financial leverage of assets to liabilities, If a company's asset-liability ratio is higher, it means that the company's financial risk is greater. Generally speaking, the asset-liability ratio of an enterprise should be controlled between $40 \%$ and $60 \%$, and $70 \%$ is considered as a high risk warning line. The real estate industry has always adopted the high-leverage model, and the asset-liability ratio is generally high. With reference to wind data and the announcement of listed real estate enterprises, the average asset-liability ratio of the industry in the past 5 years is about $78 \%$, and it has been increasing year by year. Judging from the data released by China Fortune Land Development in the 2014-2018 annual report, its assetliability ratio continued to be above $80 \%$, and as high as $88 \%$ in the first half of 2019, which shows that the asset liability ratio of China Fortune Land Development has been at a high risk level both in the industry and outside the industry. In the face of the coming debt peak, the excessive asset-liability ratio will put enterprises under huge financial pressure. Once the adverse fluctuations occur in the business process, the risks they face will be unbearable. 
Table 1 China Fortune Land Development Asset-liability Ratio Data Sheet from 2014 to 2018

\begin{tabular}{|c|c|}
\hline Year & Asset-liability Ratio (\%) \\
\hline 2014 & 84.74 \\
\hline 2015 & 84.8 \\
\hline 2016 & 84.78 \\
\hline 2017 & 81.1 \\
\hline 2018 & 86.65 \\
\hline
\end{tabular}

\subsubsection{The decrease of return on net assets increases business risk}

The rate of return on net assets reflects the ability of an enterprise to obtain net income by using its own capital and operating accumulation. It is the most comprehensive and representative index in evaluating the profitability of an enterprise. If the rate of return on net assets is higher, it means that the ability of enterprises to gain profit is stronger and the efficiency of capital operation is better.
As Shown in Table 2, according to the annual report data of China Fortune Land Development from 2014 to 2018, the return on equity of the company continued to decline from $26.87 \%$ in 2014 to $14.85 \%$ in 2017. Although it recovered to $22.15 \%$ in 2018 , it was mainly caused by the increase of equity multiplier. The equity multiplier reflects the degree of debt operation of the enterprise. The greater the equity multiplier, the more fully the company operates with debt At the same time, the greater the debt repayment pressure of the enterprise is, the greater the operation risk is.

Table 2 Data Sheet of Return Rate and Influencing Factors of China Fortune Land Development from 2014 to 2018

\begin{tabular}{|c|c|c|c|c|c|}
\hline Year & $\mathbf{2 0 1 4}$ & $\mathbf{2 0 1 5}$ & $\mathbf{2 0 1 6}$ & $\mathbf{2 0 1 7}$ & $\mathbf{2 0 1 8}$ \\
\hline Net Profit Margin on Sales(\%) & 14.14 & 13.01 & 11.46 & 14.77 & 14.08 \\
\hline Total Assets Turnover(turn) & 0.29 & 0.27 & 0.26 & 0.19 & 0.21 \\
\hline Equity Multiplier & 6.55 & 6.58 & 6.57 & 5.29 & 7.49 \\
\hline ROE(\%) & 26.87 & 23.11 & 19.58 & 14.85 & 22.15 \\
\hline
\end{tabular}

\subsubsection{The high proportion of asset-heavy increases the difficulty of business transformation}

Asset-heavy refer to the tangible assets held by the enterprise, such as inventory, fixed assets, etc., and assetlight are the intangible assets of the enterprise [2]. Assetheavy have the characteristics of more investment and longer periods. Excessively high heavy asset holding rates will cause a certain burden on the company's finances and the risks are relatively large.As shown in Table 3, judging from the data of China Fortune Land Development's annual report from 2014 to 2018, in recent years, while China Fortune Land Development has expanded,its asset structure has been continuously adjusted, but overall the asset-heavy ratio is high and the intangible asset rate is low. From 2014 to 2016, China Fortune Land Development's asset-heavy ratio decreased year by year on the high level, but due to the accelerated expansion of the new industrial city's remote replication, the company's inventory was backlogged, resulting in an increase in the asset-heavy ratio after 2017. In particular, the total inventory has increased significantly. An excessively high asset-heavy ratio will have a certain impact on the profitability of the company. Once the national control policy is tightened, it will cause the company to have a large inventory of backlogs, which is not conducive to improving the company's operating capabilities, thereby slowing down the expansion of the company. Due to the introduction of property land use rights and the introduction of players' technology by the club, the intangible asset rate of China Fortune Land Development experienced a significant increase in 2015, and the intangible asset rate reached $2.68 \%$. The accumulation of a large amount of land has neglected the increase in the intangible asset rate, which caused the intangible asset rate to gradually decline in 2017 and 2018, which is not conducive to the transformation of enterprises into assetlight. 
Table 3 Data Sheet of China Fortune Land Development-Heavy Assets Rate and Intangible Assets Rate 2014-2018

\begin{tabular}{|c|c|c|c|c|c|}
\hline Years & 2014 & 2015 & 2016 & 2017 & 2018 \\
\hline Inventory(RMB billion) & 78.316 & 100.621 & 147.345 & 229.794 & 254.523 \\
\hline Investment real estate(RMB billion) & 0.421 & 0.807 & 1.373 & 2.874 & 2.246 \\
\hline Fixed assets(RMB billion) & 1.646 & 2.379 & 2.67 & 2.842 & 5.073 \\
\hline Construction in process(RMB billion) & 1.463 & 2.219 & 3.338 & 4.267 & 12.663 \\
\hline Intangible assets(RMB billion) & 0.455 & 4.512 & 6.14 & 5.193 & 5.343 \\
\hline Total assets(RMB billion) & 113.964 & 168.623 & 249.903 & 375.865 & 409.712 \\
\hline Heavy asset ratio (\%) & 71.82 & 62.88 & 61.91 & 63.79 & 67 \\
\hline Intangible assets rate (\%) & 0.40 & 2.68 & 2.46 & 1.38 & 1.30 \\
\hline
\end{tabular}

\subsubsection{Increased financing pressure increases business operating costs}

Under the asset-heavy model, China Fortune Land Development needs to spend a lot of money in all aspects of operation and management. With the changes of market policies and environment, the development cycle of new industrial cities is long and land reserves are large, which makes the recovery period of China Fortune Land Development longer..As shown in Table 4, according to the data of China Fortune Land Development 2014-2018 annual report, days sales of inventory increased significantly in 2017 and 2018, and days sales outstanding increased year by year, which caused a large amount of sluggish working capital circulation. The sluggish capital flow makes China Fortune Land Development to make up for the shortage of working capital through a large amount of borrowing, which will inevitably increase the operating costs of the enterprise. At the same time, due to the impact of national macrocontrol policies and the economic environment, China Fortune Land Development had to bear excessive interestbearing liabilities due to restricted bank loans. Due to the emergence of these problems, the capital requirements for China Fortune Land Development', s expansion and development cannot be met, and the pressure on corporate financing has increased invisibly. At the same time, with the increase in financing costs, financial problems under assetheavy operations have become more serious.

Table 4 Data table of inventory turnover days and accounts receivable turnover days of China Fortune Land Development from 2014 to 2018

\begin{tabular}{|c|c|c|c|c|c|}
\hline Year & 2014 & 2015 & 2016 & 2017 & 2018 \\
\hline Inventory turnover days (day) & 1379.84 & 1282.97 & 1238.39 & 2185.79 & 1782.18 \\
\hline Accounts receivable turnover days(day) & 46.07 & 57.82 & 55.78 & 85.76 & 114.59 \\
\hline
\end{tabular}

To sum up, the operation model of China Fortune Land Development presents the asset-heavy model, in which the earning power and debt-paying ability are not optimistic. In order to make the company develop better, China Fortune Land Development's transformation of asset-light operation mode is imminent.

\subsection{The Necessity of China Fortune Land Development to transform the asset-Light operation mode}

\subsubsection{Reduce the impact of market fluctuations and ease corporate pressure}

Under the asset-heavy model, real estate companies have a higher degree of dependence on land, and enterprises mainly profit from the appreciation of land. China Fortune Land Development's operating income is mainly derived from the residential development and industrial development services in the park. It purchases a large amount of land to construct a new industrial city, thereby obtaining a one-time investment income. In the asset-light model, enterprises can actively develop pension real estate, education, real estate, leisure and tourism real estate and other new real estate business in order to reduce the proportion of land resources in the enterprise assets, but also to avoid single source of income, decentralized operational risk, reduce market fluctuations of enterprises so that enterprises more robust development.

\subsubsection{Reduce operating costs and ease funding crisis}

Affected by policies and the environment, the development of the real estate industry fluctuates greatly, and the growth rate of capital costs is significantly greater than the growth rate of assets. Under the asset-heavy model, in order to expand the company's territory, China Fortune Land Development will increase its dependence 
on external financing and the company's debt asset ratio will continue to rise. In terms of cash flow, the industrial new city has a long investment cycle and a slow return, which will cause it to occupy a lot of funds and make the capital cost of the company higher and higher. Under such circumstances, it is very necessary for China Fortune Land Development to carry out the asset-light transformation. The asset-light model can reduce the operating costs of enterprises and alleviate the crisis of funds, thereby ensuring the stable development of China Fortune Land Development.

\subsubsection{Improve profitability and reduce operating risks}

For the real estate industry, due to the main use of the advance payment model in the sales process, so that companies have a lot of liabilities, increasing the financial risks of real estate companies. Under the asset-heavy model, China Fortune Land Development's return on net assets continued to decline, which indicates that the assetheavy model has not been able to bring better development to enterprises. Under the asset-light mode, profits can be obtained through cooperative development and export of brand advantages. The diversification of profitable methods can make the development of the enterprise more stable, thereby improving the profitability of the enterprise, reducing the operating risk of the enterprise, and making the company better.

\subsection{Specific ways for China Fortune Land Development to transform its asset-light operation model}

\subsubsection{Choose to develop "fund + REITs" model}

The development focus of China Fortune Land Development in the future can choose to develop "fund + REITs" light asset operation model. The income of the "Fund + REITs" model mainly includes fund management fee income, property management fee income and investment return income, rather than mainly derived from real estate development income, which reflects the transformation of the main business income to the light asset operation [3]. At the same time, through the use of REITs tools to help the whole body of the industrial new city to achieve "asset-out, profit-in", so as to achieve an asset-light operation model. Specifically, the company can sell the on-balance-sheet assets of the new industrial city to contract funds to obtain property sales income and development profits; At the same time, the assets can be removed from the balance-sheet in the form of asset securitization, and the assets can be developed or acquired off-balance sheet. It can increase the leverage of the company's funds, thereby expanding the scale of the company's off-balance sheet assets and gaining actual control of the assets. However, in the process of transformation, China Fortune Land Development should master the pace of transformation, and at the same time, combine with the current policies and economic environment to avoid problems caused by the rapid transformation of the enterprise development.

\subsubsection{Exploiting new integrated real estate business}

As China Fortune Land Development's business is limited by its industrial new city development model, it will cause a large amount of funds to deposit in the early stage, and it will take a long time to pay back, so China Fortune Land Development needs to develop a business with faster capital turnover. Therefore, while developing a new industrial city, China Fortune Land Development can appropriately increase commercial real estate and related mid-to-high-end residential businesses, such as office buildings and shopping malls. The diversification and derealization of real estate development companies are the general trend. Enterprises expand their business scope to ease the impact of policies on the real estate market and slow or even hinder performance growth [4]. However, it is worth noting that, while developing new business, we must pay attention to the coordination of old business and the reasonable allocation of resources in order to prevent unreasonable resource allocation and cause new problems in the business.

\subsubsection{Focus on developing brand advantages}

As the development of China's real estate industry has entered a mature period, brand building has become increasingly important. The transformation of the real estate company's asset-light operation model needs to be based on its strong brand competitiveness. At the same time, the brand influence of the enterprise can also enhance the competitiveness of the company's products and enhance the customer's recognition of the company's products, so that the company can expand its market share and gain higher market share. Therefore, in the process of transforming the asset-light operation model, China Fortune Land Development should focus on cultivating its own brand advantages and focusing on brand operations, so as to achieve the purpose of rapid development of the enterprise. The unique industrial planning concept and layout of China Fortune Land Development and the cluster effect of the new industrial city have established a certain brand reputation for China Fortune Land Development [5]. In the future development process, China Fortune Land Development should consolidate its own brand advantages, strive for higher brand awareness, and lay the foundation for better and faster development of enterprises. 


\section{CONCLUSION}

Finally, it needs to be clear that not every real estate enterprise is suitable for the transformation of light asset operation mode directly, and the transformation also needs to have certain conditions, so before the transformation, the real estate enterprise must select its own development path according to its own actual situation..

\section{ACKNOWLEDGMENT}

First of all, I would like to thank my mentor Zhirong Shen, who is a very responsible and knowledgeable scholar who has given me valuable guidance at every stage of thesis writing. Thanks to her careful teaching, I was able to complete my thesis. Her keen and vigorous academic observation enlightens me not only in this thesis but also in my future study.

\section{REFERENCES}

[1] Yi Zhang, Analysis of the development status and future of the real estate industry, Northern Economy and Trade, vol.2, pp. 133-134, 2019.

[2] Dandan Zhang, Research on the Financial Dilemma and Financial Management System of the Asset-light Transformation of Real Estate Industry - - Taking Greentown China as an Example, Modern Business Trade Industry, vol.17, pp. 68-69, 2019.

[3] Ganghua Zhou, and Zixuan Zhou, A New Model of Asset Securitization in China's Industrial Parks-"Funds + REITs", China Real Estate, vol.11, pp. 67-73, 2018.

[4] Xuyuan Liu, and Shunhe Wang, An Analysis of the Transformation Trend of the Business Model of Real Estate Enterprises, Corporate Strategy, vol.6, pp. 87-88, 2019.

[5] Yan Zhang, Strategy for Increasing Enterprise Value Based on Asset-light Operation, Communication of Finance and Accounting, vol.35, pp. 82-85, 2017. 